\title{
Effectiveness of folic acid in unexplained infertility
}

\author{
Sujata Narendra Jadhav1, Devdatt Laxman Pitale ${ }^{2 *}$
}

\author{
${ }^{1}$ Department of Family Medicine, $171 \mathrm{MH}$ Samba, Jammu and Kashmir, India \\ ${ }^{2}$ Department of Obstetrics and Gynecology, INHS ASVINI, Mumbai, Maharashtra, India
}

Received: 03 July 2020

Accepted: 01 August 2020

\section{*Correspondence:}

Dr. Devdatt Laxman Pitale,

E-mail: dipu.pitale@gmail.com

Copyright: () the author(s), publisher and licensee Medip Academy. This is an open-access article distributed under the terms of the Creative Commons Attribution Non-Commercial License, which permits unrestricted non-commercial use, distribution, and reproduction in any medium, provided the original work is properly cited.

\begin{abstract}
Background: Folic acid is commonly used by infertile women worldwide. However, studies on the effect of folic acid in women with unexplained infertility are lacking. This aim of this study was to evaluate the effectiveness of folic acid in women with unexplained infertility.

Methods: This prospective multicentric study was performed from June 2019 to July 2020 in women with unexplained infertility attending the fertility clinic. In this study, 50 women with unexplained infertility who satisfied the inclusion and exclusion criteria were started on folic acid therapy. The effectiveness of therapy was evaluated on the basis of successful conception and adverse effects if any.

Results: Folic acid therapy showed a marked improvement in infertility status measured in terms of successful conception. After initial 12 weeks therapy successful conception was achieved in 40 (80\%) women without any adverse effects.

Conclusions: Folic acid supplementation has a positive effect on pregnancy outcome in women with unexplained infertility without any adverse effects. Folic acid is thus a safe and cost-effective option in women with unexplained infertility.
\end{abstract}

Keywords: Conception, Folic acid, Infertility

\section{INTRODUCTION}

One in ten couples worldwide has been affected by infertility and has caused severe stress in marital life..$^{1,2}$ The standard infertility treatment in form of Assisted Reproductive techniques adds to this stress and economic burden on the affected couples. ${ }^{3}$ In about $20 \%$ of couples the exact cause of infertility is unknown and are diagnosed as couples with unexplained infertility. ${ }^{4}$

Folic acid, one of the B complex vitamins, has been associated with infertility in a positive manner. ${ }^{5}$ Folic acid plays an important role in oocyte quality and maturation along with improved implantation and normal continuation of pregnancy. ${ }^{6}$ Folic acid has an important role in DNA synthesis, epigenetic modification and cell proliferation.
Folic acid deficiency affects especially proliferative cells like neural tube cells in the fetus, thus increasing the risk of neural tube defects in particular. ${ }^{7-10}$ Factors associated with folic acid deficiency are nutritional deficiency, malabsorption and may be associated with hyperhomocysteinemia. ${ }^{2}$ Pre-conceptional folic acid therapy increases folic acid concentration and decreases resultant homocysteine concentration in follicular fluid. ${ }^{11}$ This adds to improved quality of embryo and thus chances of successful conception. In addition, a study of women taking multivitamins containing folic acid showed a reduced risk of ovulatory infertility. ${ }^{12}$ Folic acid therapy in women with unexplained infertility and pregnancy outcome has not been studied extensively. Women with unexplained infertility do not normally receive a proper diagnosis as a result of the fact that a uniform definition is lacking. ${ }^{13}$ Such women might also be sub-fertile rather than infertile. 
The aim of this study was to study the effectiveness of folic acid therapy in women with unexplained infertility and successful conception. This will enable better understanding of the role of folic acid in unexplained infertility.

\section{METHODS}

The prospective multicentric observational study was conducted at infertility clinic/family OPD at $171 \mathrm{MH}$, INHS Asvini and INHS Sandhani from June 2019 to July 2020 .

\section{Inclusion criteria}

Women with unexplained infertility only were included in the present study.

\section{Exclusion criteria}

Patients with other causes of infertility such as tubal factor, male factor were excluded from the study.

In this study, 50 women with unexplained infertility who satisfied the inclusion and exclusion criteria were started on Folic acid therapy. They were started on folic acid as per the standard protocol using $5 \mathrm{mg}$ tablet once a day. Successful conception is confirmed by a positive urine pregnancy test and clinically by intrauterine gestational sac observed on USG corresponding to $6-7$ weeks of pregnancy.

In a previous study, intake of folic acid at $250 \mathrm{mcg} /$ day for 4 weeks was shown to decrease plasma homocysteine concentrations significantly and to increase mean plasma folate concentrations to $22.5 \mathrm{nmol} / 1 .^{14}$ Therefore, this plasma folate cut-off value was used to define folic acid supplement use: women with plasma folate concentrations of $22.5 \mathrm{nmol} / \mathrm{l}$ were defined as folic acid supplement users and women with plasma folate concentrations $<22.5 \mathrm{nmol} / 1$ were defined as nonusers. For assessment of pregnancy outcome in relation to folate status, women with unexplained infertility were divided into two groups according to plasma folate concentration: $22.5 \mathrm{nmol} / \mathrm{l}$ and $<22.5 \mathrm{nmol} / \mathrm{l}$.

\section{Statistical analysis}

The statistical analysis of the data thus collected is done by observational method of data analysis and computed in results respectively.

\section{RESULTS}

Of the 50 women with unexplained infertility 45 (90\%) cases were with primary infertility and $5(10 \%)$ cases with secondary infertility.
Table 1: Demographic characteristics.

\begin{tabular}{|lll|}
\hline Variable & Range & Mean \\
\hline Age (years) & $20-30$ & 26 \\
\hline Duration of infertility (years) & $2-5$ & 2 \\
\hline Primary infertility no. (\%) & $45(90)$ & 54 \\
\hline Secondary infertility no. (\%) & $5(10)$ & \\
\hline
\end{tabular}

As shown in Table 1 the mean age of women with unexplained infertility was 25 years. The mean duration of infertility 2 years.

\section{Major outcomes of the study}

Major outcomes of this study are shown in Table 2. After the initial 12-week folic acid therapy successful conception was achieved in $40(80 \%)$ of women. The remaining 10 cases are on regular folic acid therapy.

Table 2: Major outcomes of the study.

\begin{tabular}{|ll|}
\hline Outcomes & Number (\%) \\
\hline Successful conception & $40(80)$ \\
\hline Spontaneous conception & $35(70)$ \\
\hline Ovulation induction & $5(10)$ \\
\hline
\end{tabular}

This finding is significant and in line with the research conducted by Boxmeer et al. ${ }^{15}$

Folic acid therapy is effective in achieving successful conception in women with unexplained infertility.

\section{Successful conception}

Successful conception was achieved in $40(80 \%)$ patients as shown in Table 3 .

Table 3: Successful conception.

\begin{tabular}{|ll|}
\hline Successful conception & Number (\%) \\
\hline Spontaneous & $35(70)$ \\
\hline Ovulation induction & $5(10)$ \\
\hline Total & $40(80)$ \\
\hline
\end{tabular}

Out of the 40 patients with successful conception, 35 conceived spontaneously and rest with standard ovulation induction protocol as shown in Table 3.

This result is comparable to the research conducted by where successful conception rate was observed in $73 \%$ of women with unexplained infertility. ${ }^{16}$

\section{Safety profile}

No any major adverse effect was noted during the therapy. This enabled a better compliance of the patient for the 12-week folic acid therapy in this study. 


\section{DISCUSSION}

This study showed that in women with unexplained infertility folic acid therapy has a positive impact on achieving a successful conception.

A majority (80\%) of women with unexplained infertility in the present study achieved successful conception which is comparable to other studies as shown in results and is supported by the research conducted by McGuire et al. ${ }^{17}$ Study conducted by Baraka et al and Timmermans et al showed that higher educational level and age also improves the folic acid intake in women with unexplained infertility. Other factors associated with increased intake of folic acid supplements are higher age. Even in the present study, the mean age of women with unexplained infertility was higher i.e., 26 years.

The studies conducted by De wallet, Zestra et al throw light on the use of folic acid, which is strongly linked to pregnancy and prevention of neural tube defects. ${ }^{18,19}$ All this factors along with the cost effectiveness of folic acid enhances the compliance to folic acid therapy Lane. ${ }^{20}$

The recent studies have shown that folic acid therapy increases serum folate concentrations more than dietary folate, as folic acid has overall stable chemical structure and better bioavailability than naturally occurring folates (Elkin and McNulty). ${ }^{21.22}$ Also Homocysteine concentration is inversely correlated to the folate concentration in blood was found by study of Scott et al. $^{23}$

Till date, studies on folic acid supplement and pregnancy outcome in women with unexplained infertility are lacking. In the present study, the study group was well defined, as only women with unexplained infertility were included which adds to the strength of this study.

\section{CONCLUSION}

This study shows the effectiveness of folic acid therapy in women with unexplained infertility by achieving successful conception with no any major adverse effects. Folic acid therapy is a cost effective and safe option in unexplained infertility.

\section{ACKNOWLEDGMENTS}

Authors would like to thank the support of colleagues at $171 \mathrm{MH}$ Samba, INHS ASVINI, INHS Sandhani, for the completion and success of this study.

Funding: No funding sources

Conflict of interest: None declared

Ethical approval: The study was approved by the Institutional Ethics Committee

\section{REFERENCES}

1. Vayena E, Rowe PJ, Griffin PD. (Eds.), current practices and controversies in assisted reproduction. WHO, Geneva; 2002.

2. Scholl TO, Johnson WG. Folic acid: influence on the outcome of pregnancy. Am J Clin Nutr. 2000;71:1295S-303S.

3. Hassan MA, Killick SR. Negative lifestyle is associated with a significant reduction in fecundity. Fertil Steril. 2004;81:384-92.

4. Raine-Fenning NJ, Campbell BK, Kendall NR, Clewes JS, Johnson IR. Endometrial and subendometrial perfusion are impaired in women with unexplained subfertility. Hum Reprod. 2004;19:2605-14.

5. Tamura T, Picciano MF. Folate and human reproduction. Am J Clin Nutr. 2006;83:993-1016.

6. Ebisch IM, Thomas CM, Peters WH, Braat DD, Steegers-Theunissen RP. The importance of folate, zinc and antioxidants in the pathogenesis and prevention of subfertility. Hum Reprod Update. 2007;13:163-74.

7. Antony AC. In utero physiology: role of folic acid in nutrient delivery and fetal development. Am J Clin Nutr. 2007;85:598S-603S.

8. Molloy AM, Scott JM. Folates and prevention of disease. Public Health Nutr. 20001;4:601-9.

9. Nilsen RM, Vollset SE, Rasmussen SA, Ueland, PM, Daltveit AK. Folic acid and multivitamin supplement use and risk of placental abruption: a populationbased registry study. Am J Epidemiol. 2008; 167:867-74.

10. Safi J, Joyeux L, Chalouhi GE. Periconceptional folate deficiency and implications in neural tube defects. J Pregnancy. 2012:295083.

11. Wilcox AJ, Lie RT, Solvoll K, Taylor J, Mcconnaughey DR, Abyholm F, et al. Folic acid supplements and risk of facial clefts: national population-based case-control study. BMJ. 2007;334:464.

12. Boxmeer JC, Brouns RM, Lindemans J, Steegers EA, Martini E, Macklon NS, et al. Preconception folic acid treatment affects the microenvironment of the maturing oocyte in humans. Fertil Steril. 2008;89:1766-70.

13. Chavarro JE, Rich-Edwards JW, Rosner BA, Willett, WC. Use of multivitamins, intake of B vitamins, and risk of ovulatory infertility. Fertil Steril. 2008;89:668-76.

14. Brouwer IA, Van Dusseldorp M, Thomas CM, Duran M, Hautvast JG, Eskes TK. Low-dose folic acid supplementation decreases plasma homocysteine concentrations: a randomized trial. Am J Clin Nutr. 1999;69:99-104.

15. Boxmeer JC, Macklon NS, Lindemans J, Beckers NG, Eijkemans MJ, Laven JS, et al. IVF outcomes are associated with biomarkers of the homocysteine pathway in monofollicular fluid. Hum Reprod. 2009;24:1059-66. 
16. Haggarty P, McCallum H, McBain H, Andrews K, Duthie S, McNeill G, et al. Effect of B vitamins and genetics on success of in-vitro fertilisation: prospective cohort study. Lancet. 2006;367:1513-9.

17. Mcguire M, Cleary B, Sahm L, Murphy DJ. Prevalence and predictors of periconceptional folic acid uptake - prospective cohort study in an Irish urban obstetric population. Hum Reprod. 2010;25:535-43.

18. De Walle HE, De Jong-Van Den Berg LT. Ten years after the Dutch public health campaign on folic acid: the continuing challenge. Eur J Clin Pharmacol. 2008;64:539-43.

19. Zestra-Van Der Woude PA, De Walle HE, De JongVan Den Berg LT. Periconceptional folic acid use: still room to improve. birth defects research (part A): clinical and molecular. Birth Defects Res A Clin Mol Teratol. 2012;94:96-101.

20. Lane IR. Preventing neural tube defects with folic acid: nearly 20 years on, the majority of women remain unprotected. J Obstet Gynaecol. 2011;31:581-5.

21. Elkin AC, Higham J. Folic acid supplements are more effective than increased dietary folate intake in elevating serum folate levels. BJOG. 2000;107:2859.

22. Mcnulty H, Pentieva K. Folate bioavailability. Proc Nutr Soc. 2004:63:529-36.

23. is common and increases disease risk. It can be corrected by daily ingestion of supplements or fortification. Novartis Found. Symp. 2007;282:10517.

Cite this article as: Jadhav SN, Pitale DL Effectiveness of folic acid in unexplained infertility. Int J Reprod Contracept Obstet Gynecol 2020;9:3780-3. 